\title{
The Near-Death Experience and Christian Universalism
}

\author{
Ken R. Vincent, Ed.D. \\ Houston, TX
}

\begin{abstract}
I explore the near-death experience (NDE) in the context of the theology of Christian Universalism. I provide data on various models of Christian theology, and present the model of Restorative Universalism as the one most compatible with reports of afterlife in the NDE. I interface quotations from actual NDE accounts with New Testament verses to illustrate these similarities. Restorative Universalism includes a judgment ("life review" in NDE terminology), followed by punishment for some but eventual universal salvation for all. I present an analysis of New Testament verses supporting the theologies of "Jesus Saves," Predestination, Good Works, and Universal Salvation, which reveals Salvation by Good Works to be supported by the greatest number of verses, followed by verses advocating Universal Salvation for All. Christian Restorative Universalism is based upon these two predominant New Testament teachings and affords the greatest harmony with the NDE.
\end{abstract}

KEY WORDS: near-death experience; Universalist; Restorative Universalism; Christianity.

Of all the theological explanations for the near-death experience (NDE), the Doctrine of Universal Salvation, also known as Universalism, is the most compatible with contemporary NDE accounts. Universalism embraces the idea that God is too good to condemn humankind to Eternal Hell and that, sooner or later, all humanity will be saved. Interestingly, a belief in Universal Salvation can be found in virtually all the world's major religions (Vincent, 2000, pp. 6-8). It is

Ken R. Vincent, Ed.D., is retired from teaching Psychology, including the Psychology of Religious Experience, at Houston Community College. Reprint requests should be addressed to Dr. Vincent at 7300 Brompton \#5233, Houston, TX 77025; e-mail: professorvincent@yahoo.com. 
particularly essential to Zoroastrianism, the religion of the Magi (Vincent, 1999, pp. 9-10 and 46-47).

The Universalist theology that acknowledges a temporary Hellish state for those who need some "shaping up" before proceeding to their ultimate reward is termed more specifically "Restorative Universalism." In my book Visions of God from the Near-Death Experience, I included a chapter on frightening NDEs, coupled with Hell as portrayed in sacred scriptures. My intention then was to present the topic of Universal Salvation in the world's religions from a spiritual perspective (Vincent, 1994). In this article, I want to show that Christian Universalism, a doctrine with solid support in the New Testament, blends seamlessly with the experience of NDErs.

By exploring the connections between the NDE and Universalist theology, I have no interest in reviving the so-called "Religious Wars" in the NDE movement (Ellwood, 2000; Ring, 2000; Sabom, 2000a, $2000 \mathrm{~b}$ ). I do hope to offer a source of comfort to NDErs, both Christian and nonChristian, who may have had their experience marginalized by assaults from Fundamentalist or Conservative Christians. They can be assured that a more loving alternative to Christian "exclusivity" (that is, "only Christians go to Heaven") exists within the same New Testament they have known since childhood.

In a recent national poll for Religion \& Ethics Newsweekly and U. S. News \& World Report (Mitofsky International and Edison Media Research, 2002), only 19 percent of Christians and 7 percent of nonChristians stated a belief that their religion was the only true religion. This contrasted with a 1965 poll in which 65 percent of Protestants and 51 percent of Catholics reported that "belief in Jesus Christ as Savior was absolutely necessary for Salvation" (Glock and Stark, 1965).

Americans appear to be becoming more Universalist in their orientation. The 2002 study also found that "an individual's spiritual experience (as opposed to doctrines and beliefs) is the most important part of religion" was answered in the affirmative by 69 percent of Christians and 73 percent of nonChristians (Mitofsky International and Edison Media Research, 2002). Americans also appear to be more spiritually aware, or at least more willing to admit it. In 2002, 86 percent of Americans stated that they had "experienced God's presence or a spiritual force that felt very close to you one or more times" (Mitofsky International and Edison Media Research, 2002).

Spirituality has always been part of religious experience. In this article, I will explore how Universalist ideas are expressed in the 
Bible, and, more importantly, how Universalism helps place the neardeath experience within the context of Christian theology.

\section{Validity of the Bible}

To examine these questions, we must first consider the status of the Bible and theological interpretations of it. In polls regarding the validity of the Bible, about one-third of Americans reported a belief that the Bible is "the actual Word of God" (about as many as report being Fundamentalist). One-sixth (about the number of nonChristians in America) described it as a "book of fables, legends, history, and moral precepts." One-half believed it to be the "inspired Word of God but that not everything should be taken literally" (Mitofsky International and Edison Media Research, 2002, p.2; Wood, 1989, pp. 130 and 361). These views of the general population reflect modern scholarship regarding the Bible. Today, Biblical inerrancy is a view adhered to by only the most Fundamentalist scholars (Borg, 2001).

The Bible contains a treasure trove of ancient accounts of mystical religious experiences. Conservative Christian scholar Luke Timothy Johnson (1998) correctly noted that modern studies of Christian origins ignore the mystical religious experiences so clearly described in the New Testament. Moderate Christian scholar James D. G. Dunn noted, in referring to Jesus, that "there is no incidence of a healing miracle that falls clearly outside the general character of psycho-somatic illness" (1975/1997, p. 71). Nevertheless, his book is a study on what may be called "communicative theism," the direct contact between God and humanity in the New Testament. Even the liberal Jesus Seminar voiced no doubt that Jesus appeared to some of his followers after his death (Funk and The Jesus Seminar, 1998).

From the time the Bible was written to the present, individuals have reported mystical experiences (Argyle, 2000; Hick, 1999; James, 1901/ 1958). The NDE is unique among the categories of mystical union with God (Borg, 1997) because of its identifiable "trigger." The big question is: How much credibility should one give to reports of mystical experiences in the Bible, as most are not first-person accounts but rather written down as "much-told tales" following many years of oral tradition?

As stated above, most scholars do not consider the Bible to be inerrant. In light of this, it becomes untenable in theological 
interpretation to base one's theological program on one or two Bible verses. For example, the basis of papal authority is inferred from two verses in the Gospel of Matthew (Matthew 16:18-19). Even more difficult is justification for the Trinity, which is not in the Bible and can at best only be inferred by the fact that God, God's Spirit, and Jesus are mentioned together in two verses (Matthew 28:19;2 Corinthians 13:14). I will discuss further below how theology can be based on a preponderance of verses in the New Testament.

\section{Christian Universalism}

At this time, let me state that I am a Unitarian Universalist Christian and, like most Liberal Christians, I believe that God was in Jesus, but not that Jesus was God. Universalism as a theological system traces its history back to Origen (185-254 CE) (Origen, 1885/ 1994). The Universalist Church in North America was, for a time during the $19^{\text {th }}$ Century, the fifth or sixth largest denomination in the United States (Howe, 1993). The Universalist Church merged with the Unitarians in 1961, and Unitarian Universalist Christians still make up a majority of our members worldwide. In the United States, ours has developed into an interfaith church in which Unitarian Universalist Christians comprise only a minority.

As stated above, there are several variants of Christian Universalism. Some Universalists believe that God will save you "no matter what." This is a variant of "Jesus Saves" theology, except that "Jesus Saves Everybody" by his atoning sacrifice (Howe, 1993, pp. 34-35). Another variant is the belief that Christians will be saved immediately, and all others will be saved after becoming believers (Howe, 1993). Restorative Universalism assumes a judgment ("life review" in NDE terminology) and punishment for some, followed by Universal Salvation for all.

Today, most Christians who profess a belief in Universal Salvation belong to variety of other denominations. Despite their questions about doctrine, most Liberal Christians choose to remain within more mainline denominations, most often for reasons of tradition. Examples of prominent contemporary Universalist Christian theologians in other denominations are Jan Bonda of the Dutch Reformed Church (1993/1998); Tom Harpur, an Anglican (1986); John Hick of the United Reformed Church (Hick, Pinnock, McGarth, Geivett, and Phillips, 1995), and Thomas Talbott, an Independent Christian (Talbott, 1999). 
It is noteworthy that, in a addition to being a Christian scholar, Tom Harpur is a near-death researcher, and he included a strong Universalist Christian statement at the end of his book, Life after Death (1991).

Christian theologies are systems created to explain the diverse and conflicting accounts given by the various authors of the New Testament. Often theologians will arrive at differing interpretations of what the words in a particular Bible verse mean. For example, "I am the way, and the truth, and the life. No one comes to the Father except through me" (John 14:6) is a primary verse used by "Jesus Saves" theologians; however, this verse has been interpreted by Liberal Christians as meaning that salvation comes from following the teachings of Jesus, rather than through his death on the cross (Borg, 2001; Harpur, 1986; Hick, 1993a).

In an article in Christianity Today entitled, "The Gift of Salvation," Timothy George (1997) made the case for "Jesus Saves" theology by citing just 23 verses from the New Testament. By my own calculations, there were 139 verses in the New Testament supporting "Jesus Saves" theology; 551 verses supporting Salvation by Good Works, with 389 of those verses being the words of Jesus himself; and 178 verses supporting Universal Salvation, including 31 verses that speak to Hell not being permanent. It is worth noting that a fourth theological position, the Doctrine of Predestination, has 77 verses to support it (Hastings, Grant, and Rowley, 1953). One can see from the sheer magnitude of data that Salvation by Good Works has the most support, followed by Universal Salvation for All. The two taken together form the case for Christian Restorative Universalism.

\section{Universalism and the NDE}

When it comes to the near-death experience, Universalism appears to be the most compatible theological position. Why is that so? Let us explore some basics of Christian Restorative Universalism and the NDE.

\section{Out-of-Body Experiences}

NDEs often begin with an "out-of-body" experience (OBE). The Bible records this 2000-year-old OBE by St. Paul:

I know a person in Christ who fourteen years ago was caught up to the third Heaven--whether in the body or out of the body I do not know; God knows. And I know that such a person-whether in the 
body or out of the body I do not know; God knows-was caught up into Paradise and heard things that were not to be told, that no mortal is permitted to repeat. (2 Corinthians $12: 2-5)^{1}$

\section{Light}

One of the most commonly reported characteristics of a deep NDE is the experience of Light or Being of Light (Vincent, 1994). Some NDErs feel that this Light represents God or God's emissary, as in the following:

I was in the Universe and I was Light. It takes all the fear of dying out of you. It was Heavenly. I was in the Presence of God. (Vincent, 1994, p. 27)

I went directly into the Light, and my pain ceased. There was a feeling of extreme peace. (Vincent, 1994, p. 27)

God is light, and in him there is no darkness at all. (1 John 1:5)

Every generous act of giving, with every perfect gift, is from above, coming down from the Father of lights. (James 1:17)

He who is the blessed and only Sovereign, the King of kings and Lord of lords. It is he alone who has immortality and dwells in unapproachable light. (1 Timothy 6:15-16)

NDErs routinely report an immense amount of unconditional love radiating from the Being of Light:

An absolute white Light that is God-all loving. The unification of us with our Creator. (Vincent, 1994, p. 27)

I left my body, and I was surrounded by God. It didn't feel male or female, young or old, just me. I was surrounded by Love .... I looked down at the little girl in bed .... Later when I realized it was me, I was back in my body. (Vincent, 1994, p. 21)

Beloved, let us love one another, because love is from God; everyone who loves is born of God and knows God. Whoever does not love does not know God, for God is love. (1 John 4:7-8)

The steadfast love of the Lord never ceases, his mercies never come to an end. (Lamentations 3:22)

NDErs report a feeling of "Oneness with God" and a sensation of being "In God":

And deep within me came an instant and wondrous recognition: I, even I, was facing God. (Vincent, 1994, p. 23)

It is something which becomes you and you become it. I could say, "I was peace; I was love." It was the brightness... It was part of me. (Vincent, 1994, p. 29)

For in him we live and move and have our being. (Acts 17:28)

For from him and through him and to him are all things. (Romans 11:36)

One God and Father of all, who is above all and through all and in all. (Ephesians 4:6) 
Sometimes NDErs encounter Jesus in the Light:

The light was in me and between the molecules, the cells in my body. He was in me-I was in him .... I knew all things. I saw all things. I was all things. But not me; Jesus had this. As long as I was "in Him," and he was "in me," I had this power, this glory (for lack of a better word). (Vincent, 1994, p. 57)

I left but stood there wanting to help this poor soul (which was in effect me). Then I was on the third level and a voice said, "choose." I saw Jesus, the Blessed Mother, and the archangel Michael. My message was unconditional love; learn to love your family; you love others, but learn to love your family. (Vincent, 1994, p. 59)

These accounts recall the Apostle Paul's experience of Jesus. Many scholars consider his account in 1 Corinthians $15: 5-8$ as the only first-hand account of the resurrection of Jesus (Funk and the Jesus Seminar, 1998; Harpur, 1986; Hick, 1993b). Paul also provided verified secondhand accounts of Jesus' appearance to Peter and James. In Acts, we have a description of Paul's experience of Jesus:

Now as he was going along and approaching Damascus, suddenly a light from Heaven flashed around him. He fell to the ground and heard a voice saying, "Saul, Saul, why do you persecute me?" (Acts $9: 3-4$; also $22: 6-7 ; 26: 12-14$ )

Researcher Philip Wiebe (1997) maintained that there is no difference between modern-day visions of Jesus and similar visions of Jesus described in the Bible. Although Wiebe excluded NDEs from his research, numerous NDE accounts over the past quarter century attest to face-to-face meetings with Jesus. Curiously, even people of religions other than Christianity have described encounters with Jesus (Rommer, 2000).

Before turning our attention from the Light, it is worth noting that Fundamentalists often counter this common NDE phenomenon with a verse from St. Paul: "Even Satan disguises himself as a being of Light" (2 Corinthians 11:14). This is of dubious relevance for NDEs for two reasons: first, it places too much weight on a single Bible verse; and second, the overwhelming amount of data leaves no doubt that the Light experienced by the NDEr radiates love. Jesus told us how to distinguish false prophets: "You will know them by their fruits" (Matthew 7:16). When Jesus himself was accused of being Satanic, he explained:

And the scribes who came down from Jerusalem said, "He has Beelzebub and by the ruler of the demons he casts out demons." And he called to them and spoke to them in parables, "How can Satan cast 
out Satan? If a kingdom is divided against itself, that kingdom cannot stand. And if a house is divided against itself, that house will not be able to stand. And if Satan has risen up against himself and is divided, he cannot stand, but his end is come." (Mark 3:22-26)

Fundamentalist Christians cannot have it both ways. The Light cannot represent goodness for a Christian and deception for nonChristians. Satan may be a neon sign, but God is the Light of the Universe.

Jesus told us that God is our Father too:

I am ascending to my Father and your Father, to my God and your God. (John 20:17)

You have one Father--the one in heaven. (Matthew 23:9)

"I will be your Father and you shall be my Sons and Daughters" says the Lord Almighty. (2 Corinthians 6:18)

Is there anyone among you who, if your child asks for bread, would give him a stone? Or if the child asks for a fish, would give a snake? If you then who are evil, know how to give good gifts to your children, how much more will your Father in Heaven give good things to those who ask Him? (Matthew 7:9-10)

What kind of parent abandons his or her child? Surely not the loving God Jesus talked about.

\section{Judgment or Life Review}

Judgment, in NDE terminology, is called "life review." This is usually a positive experience:

I found myself in a corridor. The corridor did not end. I was not afraid. There was a white light. Very clear white colors of light. Off to the side, I could see shades of gray. Off to the side, I could see my childhood passing, going left to right. I thought to myself, "I am getting younger." I did not see my adult life. I felt like I was not alone, but I did not see anybody. (Vincent, 1994, p. 95)

During the Judgment [it was] like on a Rolodex. I could feel the person by me. I was waiting for the bad to come up, but nothing bad was coming up. (Vincent, 1994, p. 93)

For others, there is a perception of one's effect on other people:

I saw this life "pass in front of my eyes," like watching a movie. I felt others' pain, joy, sorrows. (Vincent, 1994, p. 93)

For some, life review is a negative experience:

It was not peaceful, much baggage, much unfinished business. All things are connected. You are not your body, you are a soul; mine was in limbo. I knew I would be in limbo for a long time. I had a life review and was sent to the void. (Vincent, 1994, p. 119) 
In Christianity, sometimes God is seen as Judge of the World, but more often, Jesus is seen as the Judge (Ma'súmián 1996). In Jesus' parable of the Rich Man and Lazarus (Luke 16:19-31), he stated that judgment began prior to him, was ongoing, and occurred immediately after death. In the Judgment of the Nations (Matthew 25:31-46), Jesus is Judge of all the world, both Christian and nonChristian. Judgment is based on good works done to the "least of these" (Matthew 25:40).

Jesus taught that we must be judged, but that God is Light and goodness: "God is light, and in Him there is no darkness at all" (1 John 1:5). NDErs often note that the Being of Light in the life review offers total acceptance:

My near-death experience was before Moody's book came out. When it did, I said, "Oh my God! Mine is pretty classic-just like the book. It was incredibly clear-my life-going through what happened. There were figures around I did not know. The white Light was wonderful! It was just love. I knew my life would be reviewed. It was like flipping pages. I knew I had done things I was not proud of, but there was total acceptance. I wanted to stay, but I was told to go back and be loving. (Vincent 1994, p. 91)

I have already noted above that this is also true when the Being of Light is specifically identified as Jesus. This is the picture that the New Testament presents of Jesus. In the mystic Gospel of John we read:

You judge my human standards. I judge no one. (John 8:15)

And I, when I am lifted up from the Earth, will draw all people to myself. (John 12:32)

Jesus said: "My yoke is easy, and my burden is light" (Matthew 11:30). The following makes it clear that Jesus is an advocate for both Christians and nonChristians:

My children, I am writing these things to you so that you may not sin.

But if anyone does sin, we have an advocate with the Father; Jesus Christ the Righteous. He is the atoning sacrifice for our sins, and not for ours only, but also for the sins of the whole world. (1 John 2:1-2)

With Jesus as Judge, no one is ever abandoned-Christian or nonChristian. Jesus told us that the Kingdom of God is not only for the pure (Matthew 5:8) but also for the impure (Matthew 15:2, Luke 18:10-14), the pagan (Matthew 15:21-28), and the heretic (Luke 10:25-37; John 4:16-30). NDErs often feel that they judge themselves, as these quotes from three NDErs indicate:

You are judging yourself. You have been forgiven all your sins, but are you able to forgive yourself for not doing the things you should 
have done and some little cheaty things that maybe you've done in your life? This is the judgment. (Ring and Valarino, 1998, p. 167)

I didn't see anyone as actually judging me. It was more like I was judging myself on what I did and how that affected everyone. (Ring and Valarino, 1998, p. 167)

I told the Light that . . . I expected him to judge me rather sternly. He said, "Oh, no, that doesn't happen at all." However, at my request, they then played back over the events that had occurred in my life ... and I was the judge. (Ring and Valarino, 1998, p. 167)

Jesus clearly told us:

Do not judge, so that you may not be judged. For with the judgment you make you will be judged, and the measure you give will be the measure you get. (Matthew 7:1-2)

The judgment of Jesus is not based on belief in Doctrine. The test is not about correct belief, but good deeds:

Not everyone who says to me, "Lord, Lord," will enter the Kingdom of Heaven, but only the one who does the will of my Father in Heaven. (Matthew 7:21)

Good deeds will be rewarded:

For the Son of Man is to come with his angels in the glory of his Father, and then he will repay everyone for what has been done. (Matthew 16:27)

St. Peter reiterated:

I truly understand that God shows no partiality, but in every nation, anyone who fears him and does what is right is acceptable to Him. (Acts 10:34-35)

St. Paul said:

For he will repay according to each one's deeds. (Romans 2:6)

For God shows no partiality. (Romans 2:11)

St. John of Patmos wrote:

And the dead were judged according to their works as recorded in the books. (Revelation 20:12)

\section{Hell Is Not Permanent}

The experience of Hell has been recorded in NDEs since the beginning of modern research (Richie and Sherrill, 1978). In current near-death research terminology, these are called "frightening" NDEs. 
In religious terms, the place of punishment is called variously "Hell," "Hades," "Limbo," "Purgatory," "Gehenna," and "Eternal Punishment." Modern day near-death researchers have about as many types of frightening NDEs (Atwater, 1992; Greyson and Bush, 1992; Rommer, 2000 ) as the ancient and medieval authors had categories of Hell (Zaleski, 1987). Often in the NDE, accounts of Hell are not permanent:

I was in Hell... I cried up to God, and it was by the power of God and the mercy of God that I was permitted to come back. (Rommer 2000, p 42)

God, I am not ready, please help me.... I remember when I screamed (this) an arm shot out of the sky and grabbed my hand and at the last second I was kept from falling off the end of the funnel, the lights flashing; and the heat was really something. (Greyson and Bush, 1992, p.100)

If Hell is not permanent, one might wonder why Jesus said the "goats" will endure "eternal punishment" (Matthew 25:46). Universalist scholar Thomas Talbott noted that the Greek word for "forever" is better understood as "that which pertains to an age" (1997, pp. 8692). For example, when Jonah was swallowed by the great fish, he "went down to the land whose bars closed on me forever" (Jonah 2:6). However, the story ended when Jonah was released by God from his bondage after just three days. In other instances-his parable of the unforgiving servant (Matthew 18:34-35) and his descriptions of a prisoner's fate (Matthew 5:25-26, Luke 12:59)—Jesus indicated that punishment is not eternal but lasts only until one's entire debt is paid (Matthew 18:34). The following are classic passages supporting Christian Universalism (Howe, 1993, pp 34-35):

For Christ also suffered for sins once and for all, the righteous for the unrighteous, in order to bring you to God. He was put to death in the flesh, but made alive in the Spirit in which also he went and made a proclamation to the spirits in prison, who in former times did not obey. (1 Peter 3:18-20)

For this reason the Gospel was proclaimed even to the dead, so that though they had been judged in the flesh as everyone is, they might live in the Spirit as God does. (1 Peter 4:6)

\section{Universal Salvation}

According to Christian Universalism, in the end, we will all be united with God. Two of Jesus' most poignant parables proclaim Universal Salvation. In Matthew, God (the Good Shepherd) sought and saved the 
lost sheep; the sheep did not return to the flock of its own accord. The parable ends, "So it is not the will of your Father in Heaven that one of these little ones should be lost" (Matthew 18:14). In the story of the Prodigal Son (Luke 15:11-32), the returning son did not ask to be a member of the family, but for a job as his father's servant. It was God (the father) who took him back into the family. The father was the character with the active role. People often have difficulty with this story because they wrongly identify with the good son and not with the father. Considering how much human parents love their own children, the story puts some perspective on how much God, who is all good, loves each of us. This theme is echoed in the mystic Gospel of John:

I have other sheep that do not belong to this fold, and I must bring them also, and they will listen to my voice. So there will be one flock, one shepherd. (John 10:16)

And I, when I am lifted up from the earth, will draw all people to myself. (John 12:32)

Universal salvation is reiterated in numerous writings of the other Apostles:

When all things are subjected to him then the Son himself will also be subjected to the one who put all things in subjection under him, so that God may be all in all. (1 Corinthians 15:28)

For to this end we toil and struggle, because we have our hope set on the living God, who is the Savior of all people, especially of those who believe. (1 Timothy 4:10)

And the Holy Spirit also testifies to us, for after saying, "This is the covenant I will make with them after those days, says the Lord: I will put my laws in their hearts and I will write them on their minds," he also adds: "I will remember their sins and their lawless deeds no more." Where there is forgiveness of these, there is no longer any offering for $\sin$. (Hebrews 10:15-18)

He has made known to us the mystery of his will, according to his good pleasure that he set forth in Christ, as a plan for the fullness of time, to gather up all things in him, things in heaven and things on earth. (Ephesians 1:9-10)

For the grace of God has appeared, bringing salvation to all. (Titus 2:11)

\section{Aftereffects}

One of the most profound aspects of the NDE is its aftereffects (Greyson, 2000). Experiences of God change and affirm lives, and sometimes this represents a "soft" change: 
It took some time for me to realize I was consumed with an insatiable thirst for knowledge. Dr. Pat Fenske wrote in the June, 1991, Vital Signs newsletter that individuals shift to a higher level of consciousness. This I can relate to 100 percent and this has enabled me to understand why I look at things from an entirely different perspective than most people. (Vincent, 1994, p. 109)

Why did this experience change me so greatly? Why am I convinced that this was the most real thing that ever happened to me when logic and common sense dictate it wasn't? Why so many unexplained events since then? .... The experience left me a changed person but not knowing why, full of questions and still seeking answers. (Vincent, 1994, p. 113)

In some cases, the changes following an NDE are dramatic-as lifechanging as St. Paul's mystical religious vision of Jesus that transformed him from a persecutor of Christians to an Evangelist for Jesus (1 Corinthians 15:3-8; Galatians 1:13-16). That kind of powerful effect occurred in the life of art professor Howard Storm, who, after his encounter with Jesus during his NDE, abandoned his atheism and became a Christian minister. Storm related that when he began to pray, his NDE changed from a Hellish experience to a positive, loving one: "Simply stated, I knew God loved me" (Ring and Valarino, 1998, p. 292).

\section{Summary}

Like NDEs, deathbed visions (Osis and Haraldsson, 1977) and postdeath visions (Kircher, 1995) point to an afterlife. But NDEs, like mystical religious experiences throughout the ages (Argyle, 2000; James, 1901/1958), are especially rich in insights as to the nature of God. NDEs, like other mystical religious experiences, both complement and continue the testimony of that great repository of Western mystical experience, the Bible.

God's love is greater than we imagine or than we can imagine-this is the testimony of the prophets, sages, saints, mystics, and ordinary people throughout the ages who have shared with us their incomparable sense of Oneness with God and God's unconditional love for us all. Truly God is with us always and, in time, "All flesh shall see the salvation of God" (Luke 3:6).

\section{Notes}

${ }^{1}$ All Scripture quotations in this article are from the New Revised Standard Version Bible (NRSV), copyright $@ 1989$ by the Division of 
Christian Education of the National Council of the Churches of Christ in the U.S.A. Used by permission. All rights reserved.

\section{References}

Argyle, M. (2000). Psychology and religion: An introduction. New York, NY: Routledge. Atwater, P. M. H. (1992). Is there a Hell? Surprising observations about the near-death experience. Journal of Near-Death Studies, 10, 149-160.

Bonda, J. (1998). The one purpose of God: An answer to the doctrine of eternal punishment. Grand Rapids, MI: William B. Eerdmans. (Original work published 1993)

Borg, M. (1997). The God we never knew: Beyond dogmatic religion to a more authentic contemporary faith. San Francisco, CA: HarperSanFrancisco.

Borg, M. (2001). Reading the Bible again for the first time: Taking the Bible seriously but not literally. San Francisco, CA: HarperSanFrancisco.

Dunn, J. D. G. (1997). Jesus and the Spirit: $A$ study of the religious and charismatic experience of Jesus and the first Christians as reflected in the New Testament. Grand Rapids, MI: William B. Eerdmans. (Original work published 1975)

Ellwood, G. F. (2000) Religious experience, religious worldviews, and near-death studies. Journal of Near-Death Studies, 19, 5-21.

Funk, R.W., and The Jesus Seminar. (1998). The Acts of Jesus: The search for the authentic deeds of Jesus. San Francisco, CA: HarperSanFrancisco.

George, T. (1997, December 8). The gift of salvation. Christianity Today, pp. 35-37.

Glock, C. Y., and Stark, R. (1965). Religion and society in tension. Chicago, IL: Rand McNally.

Greyson, B. (2000). Near-death experiences. In Cardeña, E., Lynn, S. J., and Krippner, S. (eds.), Varieties of anomalous experience: Examining the scientific evidence (pp.315352). Washington, DC: American Psychological Association.

Greyson, B., and Bush, N. E. (1992). Distressing near-death experiences. Psychiatry, 55, 95-110.

Harpur, T. (1986). For Christ's sake. Toronto, Canada: McClelland and Stewart.

Harpur, T. (1991). Life after death. Toronto, Canada: McClelland and Stewart.

Hastings, J., Grant, F. C., and Rowley, H. H. (eds.). (1953). Dictionary of the Bible. New York, NY: Scribner's.

Hick, J. (1993a). Disputed questions in theology and the philosophy of religion. New Haven, CT: Yale University Press.

Hick, J. (1993b). The metaphor of God Incarnate: Christology in a pluralistic age. Louisville, KY: Westminster/John Knox Press.

Hick, J. (1999) The fifth dimension. Boston, MA: One World.

Hick, J., Pinnock, C. H., McGarth, A. E., Geivett, R. D., and Phillips, W.G. (1995). More than one way? Grand Rapids, MI: Zondervan.

Howe, C. A. (1993). The larger faith: A short history of American Universalism. Boston, MA: Skinner House.

James, W. (1958). The varieties of religious experience. New York, NY: Signet. (Original work published 1901).

Johnson, L. T. (1998). Religious experience in earliest Christianity: A missing dimension in New Testament studies. Minneapolis, MN: Fortress Press.

Kircher, P.M. (1995). Love is the link: A hospice doctor shares her experience of neardeath and dying. Burdett, NY: Larson Publications.

Ma'súmián, F. (1995). Life after death: A study of the afterlife in world religions. Oxford, England: One World. 
Mitofsky International and Edison Media Research. (2002). Exploring religious America. Religion \& Ethics Newsweekly, May 10, 2002. Retrieved May 16, 2002, from: www.pbs.org/wnet/religionandethics/week534/specialreport.html

Origen. (1994). Origen De Principiis. In Roberts, A. R., and Donaldson, J. (eds.) AnteNicene Fathers, Volume 4 (pp. 260-279). Peabody, MA: Hendrickson Publishers. (Roberts and Donaldson original work published 1885)

Osis, K., and Haraldsson, E. (1977). At the hour of death. New York, NY: Avon.

Richie, G. G., and Sherrill, E. (1978). Return from tomorrow. Old Tappan, NJ: Sprite.

Ring, K. (2000). Religious wars in the NDE movement: Some personal reflections on Michael Sabom's Light and Death. Journal of Near-Death Studies, 18, 214-244.

Ring, K., and Valarino, E. E. (1998). Lessons from the light: What we can learn from the near-death experience. New York, NY: Plenum/Insight.

Rommer, B. R. (2000). Blessing in disguise: Another side of the near-death experience. St. Paul, MN: Llewellyn.

Sabom, M. (2000a). Response to Kenneth Ring's "Religious wars in the NDE movement: Some personal reflections on Michael Sabom's Light and Death." Journal of NearDeath Studies, 18, 245-271.

Sabom, M. (2000b). Response to Gracia Fay Ellwood's "Religious experience, religious worldviews, and near-death studies." Journal of Near-Death Studies, 19, 23-44.

Talbott, T. (1997). The inescapable love of God. Parkland, FL: Universal Publishers.

Vincent, K. R. (1994). Visions of God from the near-death experience. Burdett, NY: Larson.

Vincent, K. R. (1999). The Magi: From Zoroaster to the "Three Wise Men." North Richland Hills, TX: Bibal Press.

Vincent, K. R. (2000). Unitarian and Universalist concepts of salvation in the Bible and world religion. Universalist Herald, 152(5), 4-8.

Wiebe, D. H. (1997). Visions of Jesus: Direct encounters from the New Testament to today. New York, NY: Oxford University Press.

Wood, F. W. (1989). An American profile-Opinions and behavior 1972-1989. Chicago, IL: National Opinion Research Center.

Zaleski, C. (1987). Otherworld journeys: Accounts of near-death experience in medieval and modern times. New York, NY: Oxford University Press. 